\title{
Mapping snowpack distribution over large areas using GIS and interpolation techniques
}

\author{
Juan I. López-Moreno ${ }^{1,2, *}$, Sergio M. Vicente-Serrano ${ }^{1}$, Siham Lanjeri ${ }^{3}$ \\ ${ }^{1}$ Instituto Pirenaico de Ecología, Consejo Superior de Investigaciones Científicas (CSIC), Campus de Aula Dei, PO Box 202, \\ Zaragoza 50080, Spain \\ ${ }^{2}$ Climate Change and Climate Impacts Group, University of Geneve, 7 Route de Drize, Geneve 1227, Switzerland \\ ${ }^{3}$ Departamento de Geografía y Ordenación del Territorio, Universidad de Zaragoza, Campus de San Francisco, \\ Zaragoza 50009, Spain
}

\begin{abstract}
The objective of this study was to provide a simple and accurate method for mapping long-term averages of monthly snowpack (from 1986 to 2003) over large regions at a resolution suitable for management purposes (cell size $100 \mathrm{~m}^{2}$ ). The proposed method requires few data and overcomes the problem of the limited availability of meteorological information in mountainous areas. In a case study, the proposed method is applied to the Aragón region, NE Spain. Distributed layers of monthly temperature (maximum and minimum) and precipitation are combined to compile maps of the potential magnitude of snowpack at a monthly timescale over the entire study region. Temperature and precipitation grids were obtained using interpolation techniques and data from several weather stations. Maps of snowpack magnitude were obtained for January, March, and April. For these months, it was possible to verify the results in the north of the study area using in situ snowdepth measurements for the Central Pyrenees. The results demonstrate that the maps of potential snowpack magnitude provide a reliable estimate of the observed snow-depth distribution over the study region. Calibration between the observed and predicted values enabled us to convert the potential snowpack magnitude (in dimensionless units) into real snowpack values in absolute units (snow depth, cm). The addition of a model of incoming solar radiation in the calculation procedure provided better results in terms of the final predictions because it captured local variations in snowpack related to variable relief.
\end{abstract}

KEY WORDS: Snowpack prediction · Geographical Information Systems · Temperature • Precipitation · Incoming solar radiation $\cdot$ Pyrenees $\cdot$ Aragón $\cdot$ Spain

\section{INTRODUCTION}

Accurate quantification of the snowpack and snow water equivalent is of great importance to a number of research fields and tasks related to environmental, hydrological, and agricultural management; however, the distribution of snow is one of the most difficult variables to model at a regional scale (Haefner et al. 1997). In a number of regions around the world, snow thickness and snow conditions control various environmental processes and economic activities such as hydropower production, agricultural production, the use of livestock pastures, and winter tourism; there- fore, an appropriate knowledge of the snowpack distribution is required to optimize management policies.

Notable efforts to adequately map the distribution of snow have been made in previous studies (e.g. Haefner et al. 1997, Elder et al. 1998, Fassnacht et al. 2003); however, most of the techniques employed in these studies require intensive measurements of snow depth and density or dense databases of meteorological variables to model the energy and mass balance of the snow. Unfortunately, it is not easy to carry out regular snow courses or establish a dense network of well-equipped weather stations, especially in mountainous areas. For management purposes, it is impor- 
tant to map large areas; consequently, difficulties related to data availability increase in severity as the area of interest increases in size.

A number of methods have been designed to overcome these drawbacks, but they also have practical limitations. For example, estimates of snow accumulation and melting based on Degree-Day Models (DDMs), which require fewer data but which must be collected at least daily and require an appropriate estimate of the degree-day factor, are subject to a high degree of variability in both time and space (Martinec et al. 1994, Singh \& Singh 2001). Airborne and satellite techniques enable estimates of snow depth and snow water equivalent (e.g. Carroll et al. 2003, Marchand et al. 2003); however, these methods are complex and expensive, and observations of deep snow in rugged mountain terrain are problematic (Elder et al. 1998).

The purpose of this study was to map long-term averages of snow magnitude on a monthly time scale from easily available climatic data. The usefulness of different temporal resolutions in studies of snow depth depends on the management strategies or objectives of the research. Thus, when the objective is to develop short-term plans or early-warning systems as a response to individual meteorological events such as intense snowfall or melting events, information is required at a high temporal resolution (e.g. daily to weekly). In a practical sense, such data can be used to improve flood control measures, define areas at risk of inundation or avalanche, and assess the possible effects of meteorological events on transport infrastructure. Information obtained at medium and large temporal resolutions (e.g. monthly or seasonal) is an appropriate management tool for long-range planning and is useful in various research fields. The monthly timescale used in this study is required to explain hydrological variations within a territory, the distribution of plants and animals, and the amount of water stored in the solid state during winter; the latter is of interest when selecting suitable areas in which to develop ski resorts.

The method proposed in the present study is based on the creation of distributed layers of long-term averages (from 1986 to 2003) of precipitation and temperature (maximum, minimum, and average) modelled from a dense network of meteorological stations. An appropriate combination of the layers enabled us to shape the mass balance of snowpack: potential accumulation and melting over the entire region. Next, we verified and calibrated the index using the observed depths of snow in mountainous areas; this enabled us to convert the dimensionless units of the index to values of snow depth for the entire region. Geographical Information Systems (GIS) are a key element of the methodology because they enable the combination of the different layers and algebraic operations (Burrough \& McDonnell 1998).

We applied the method to mapping the long-term average snowpack over Aragón, a $47452 \mathrm{~km}^{2}$ region in NE Spain. The input information required (precipitation and temperature data) is commonly recorded in most areas of the world. Digital Elevation Models (DEMs) required to model the different distributed layers used in this method are available for the entire earth at detailed spatial resolutions, as provided by the Shuttle Radar Topography Mission (SRTM) (http:// srtm.usgs.gov; Rabus et al. 2003). Accordingly, the proposed method can be used to compile snowpack maps for many areas of the world, thereby overcoming the common problem of limited information from which to determine snowpack data.

\section{STUDY AREA}

Aragón, located in the NE Iberian Peninsula, is one of the largest and most topographically varied regions in Spain. An elevation map of the entire region is shown in Fig. 1. The main mountain ranges in Aragón are the Pyrenees (northern Aragón) and the Iberian Range (southeastern Aragón). Both sets of ranges mark the limits of the Ebro Depression, which is a relatively flat area within central Aragón. The elevation within Aragón ranges from less than $300 \mathrm{~m}$ above sea level (a.s.l.) in the middle of the Ebro Depression to more than $3000 \mathrm{~m}$ a.s.l. in the Pyrenees and $2000 \mathrm{~m}$ a.s.l. in the highest peaks of the Iberian Range (see Fig. 1). The heterogeneous topography and influence of different winds (Vicente-Serrano \& López-Moreno 2006) generate a complex spatial distribution of climatic parameters and contrasting values of precipitation and temperature throughout the region. Thus, annual precipitation varies between 303 and $1764 \mathrm{~mm} \mathrm{yr}^{-1}$ throughout the region, and the average annual temperature varies from 0.8 to $16.2^{\circ} \mathrm{C}$.

During winter, the height of the mean $0^{\circ} \mathrm{C}$ isotherm is around $1650 \mathrm{~m}$ (García-Ruiz et al. 1986). Areas above this threshold, which total $2759 \mathrm{~km}^{2}$ in Aragón, are favourable sites for the development of long-lived and continuous snowpack. Although the total area above the threshold constitutes just $5.8 \%$ of the region, it represents a valuable reservoir of water resources for the Ebro river (López-Moreno \& García-Ruiz 2004) and an ideal base for developing winter tourism activities. In addition, individual snowfall events occur frequently across wide areas of Aragón and can occur sporadically anywhere in the region, resulting in problems such as disruptions to traffic and the temporary isolation of villages. 


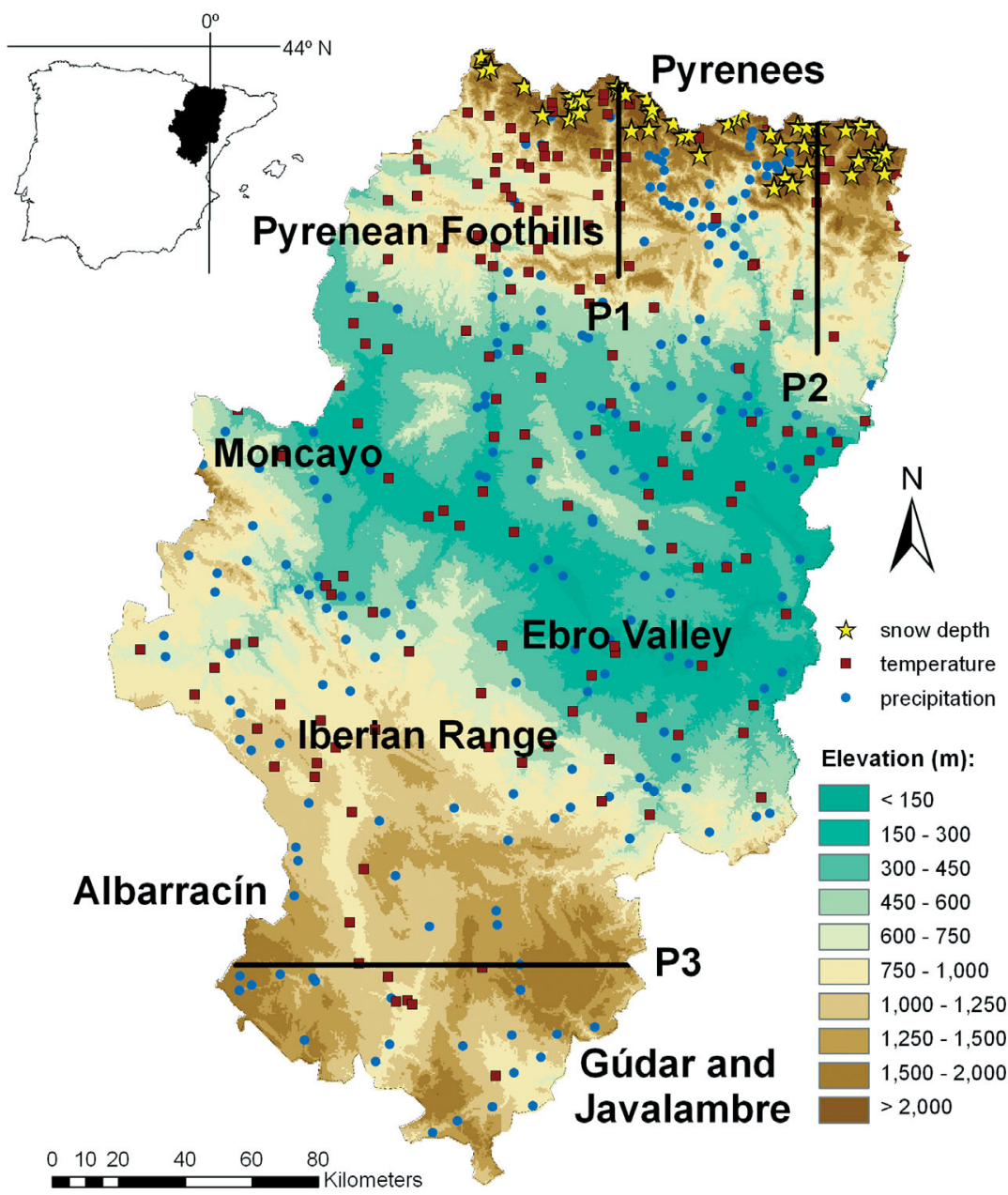

Fig. 1. Topography of the study area (Aragón region, Spain) showing locations of profiles (P1, P2, P3) analysed in Fig. 4, precipitation gauges, temperature sensors, and snow depth observations

\section{DATA AND METHODS}

\subsection{Data}

We obtained monthly totals of precipitation and average maximum and minimum temperatures from 250 and 134 weather stations throughout Aragón, respectively. These stations form a dense network over the Aragón region and surrounding areas (see Fig. 1) and are managed by the Instituto Nacional de Meteorología (National Institute of Meteorology). We then calculated monthly averages of precipitation and minimum and maximum temperatures for the period from 1985-86 to 2003. The selection of this particular time period was based on the availability of snow-depth data for the Pyrenees. The climatic data series were subjected to a process of quality control (GonzálezRouco et al. 2001) and homogenization testing. The Standard Normal Homogeneity Test (SNHT; see
Alexandersson 1986) was employed to identify and correct temporal inhomogeneities in the series (Peterson et al. 1998), which can arise from the movement of meteorological stations within the same locality. The freeware ANCLIM (P. Štìpánek unpubl.; available at www. Klimahom.com/software/AnClim.html) was used to perform the test. ANCLIM contains several comprehensive tools for quality control and the homogenization of climatic time series.

Snow depth data were obtained from 106 snow poles that were erected in the Pyrenean range during 1985; 49 of the snow poles are located in the Aragonaise sector of the Pyrenees. The snow poles are managed by the Estudio de los Recursos Hídricos Invernales (ERHIN: Study of Winter Water Resources) Programme, which aims to quantify water resources in Spain that are related to snow accumulation. From January 1986, snow depth was measured 3 times a year during January, March, and in the period from late April to early May. The locations of the snow poles (see Fig. 1) are designed to be representative of the larger surrounding area, avoiding local anomalies caused by wind or snow avalanches (López-Moreno 2005). Apart from the data derived from the snow poles, there are no long-term data on snow accumulation for the study area.

Given the lack of adequate information on snow accumulation throughout most of the study region, we estimated the potential snow accumulation according to the following steps: (1) modelling the spatial distribution of long-term averages of temperature and precipitation; (2) combining the climatic layers to classify the study area according to the long-term average potential magnitude of the snowpack over the territory; (3) verifying the obtained maps of potential magnitude from a comparison with snow-depth observations undertaken in the Pyrenees; and (4) calibrating the estimates using snow-depth data available for the Pyrenees.

\subsection{Modelling the spatial distribution of precipitation and temperature}

We used the average values of monthly maximum and minimum temperature and precipitation recorded at the various weather stations from 1970 to 2003 to 
compile distribution maps at a resolution of $100 \mathrm{~m}^{2}$. The available stations were split into 2 groups: $80 \%$ of the stations were used for modelling, and the remaining $20 \%$ were reserved to validate the maps.

To make the maps, we used a DEM obtained from the SRTM (see above). To map the climate variables, we used stepwise linear models, one of the most widely used and accurate techniques based on multiple regression analysis (Burrough \& McDonell 1998). This technique considers different auxiliary variables as the predictor, in addition to precipitation and temperature data, to improve the accuracy involved in the calculation of the climatic maps. Such regression-based methods are widely used to map climate variables (e.g. Agnew \& Palutikof 2000, Ninyerola et al. 2000), including local snow-depth data.

This procedure provides predictions on the basis of the linear relationships between the climate variable and the predictor variables, using the following transference function:

$$
z(x)=b_{0}+b_{1} P_{1}+b_{2} P_{2}+\ldots+b_{n} P_{n}
$$

where $z$ is the predicted value at point $x, b_{0} \ldots b_{n}$ are the regression coefficients, and $P_{1} \ldots P_{n}$ are the values of the predictor variables at point $x$. The selected level of significance was $\mathrm{p}<0.05$. More details of the calculation procedure can be found in Vicente-Serrano et al. (2003).

The majority of the auxiliary variables were extracted from the DEM on the basis of the close relationship between climate and topography (e.g. Basist et al. 1994, Daly et al. 1994). Topographic variables stress the impact of altitude and slope aspect in explaining the spatial distribution of climatic variables. Other terrain variables were also used as predictors because of their important role in determining climate. We included the position of each cell with respect to the different air masses that arrive in the region (mostly from the Mediterranean and Atlantic) and which exert a significant control on the regional climate (Vicente-Serrano $\&$ Cuadrat 2007). These variables were taken into account via 2 layers in which the distance to the Mediterranean Sea and the Atlantic Ocean was calculated using several GIS tools that enable estimates of the distance from a cell to a selected vector. In the same way, variables related to the effect of thermal inversion (distances to rivers and depths of valleys) were used to model minimum temperature.

Potential incoming solar radiation was used as an indicator of the orientation of the slopes with regard to the main humid air masses that affect the region. Orographic effects at different spatial scales were also taken into account by applying various low-pass filters (averages within circles with radii of $2.5,5$, and $10 \mathrm{~km}$ centred around each grid point) to the topographic variables.
Thus, independent variables used for the regressionbased interpolation were:

- Longitude

- Latitude

- Distance to the Mediterranean Sea

- Distance to the Atlantic Ocean

- Distance to the main divide

- Mean elevation within a radii of 2.5, 5 and $10 \mathrm{~km}$

- Incoming solar radiation within a radii of 2.5, 5 and $10 \mathrm{~km}$

- Distance to the centre of the valley

- Distance to rivers

We interpolated the residuals of all the available observations (differences between the predicted and observed values at station locations) to obtain more accurate predictions, following the method of Ninyerola et al. (2000) and Agnew \& Palutikof (2000). The residuals were interpolated using a local method of splines with tension. This method was selected for 2 reasons: (1) the degree of accuracy of the error estimators compared with those obtained using other local interpolators (see Vicente-Serrano et al. 2003), and (2) the fact that splines adjust more readily to local abrupt anomalies than other methods. Following this, interpolated residuals were subtracted from the original maps to correct possible local deviations from the general models and derive real climate predictions for station sites.

\subsection{Estimation of an index of potential magnitude of snowpack}

Precipitation and temperature data enable a synthesis of the main components of the mass balance of snowpack (Brown 1999, Singh \& Singh 2001). Thus, snow accumulation results from a combination of precipitation and suitable temperatures, generally considered to be around $0^{\circ} \mathrm{C}$ (Singh \& Singh 2001, Fassnacht \& Soulis 2002). Temperature shows a strong correlation with several components of the energy balance (i.e. atmospheric radiation and sensible heat flux), explaining most of the melting rates observed over a given territory (Hock 2003, Shamir et al. 2006).

Accordingly, we obtained indices related to snow accumulation and melting processes from a rational combination of the layers obtained from long-term averages of temperature and precipitation (1986 to 2003). A combination of the indices enabled us to obtain the potential magnitude of the snowpack over the territory. This procedure enabled us to deal with the lack of reliable information and develop more physically based approaches for modelling the snowpack depth. 
The indexes for each month were calculated according to the following steps:

(1) The proportion of precipitation that falls in a solid state (Precip_snow) was approached from climate layers. For this purpose, the long-term average precipitation $(P)$ of cell $x$ in month $i$ was weighted according to the long-term average maximum $\left(\operatorname{Tmax}_{X, i}\right)$ and minimum $\left(T \min _{x, i}\right)$ temperatures. The weighting procedure was as follows:

- For areas in which Tmax $<0$, Precip_snow ${ }_{X, i}=P_{X, i}$, because it is expected that the majority of precipitation will occur in a solid state;

- For areas in which Tmin $>0$, Precip_snow ${ }_{X, i}=0$, because it is expected that most of the precipitation will occur in a liquid state;

- For areas where $T \max >0$ and $T \min <0$, precipitation was weighted linearly (Eq. 2) between 0 and 1, because it is expected that a fraction of the precipitation will occur as rain and a fraction as snow. The values of Precip_snow for each cell under such a situation ( Tmax $>0$ and $T \min <0$ ) were obtained according to the following equation:

$$
\text { Precip_snow } x_{x, i}=P_{x, i}\left(1-\frac{T \max _{x, i}}{T \max _{x, i}-T \min _{x, i}}\right)
$$

where $\operatorname{Tmax}_{x, i}$ is the maximum temperature of cell $x$ in month $i$ and $\operatorname{Tmin}_{x, i}$ is the minimum temperature of cell $x$ in month $i$. Thus, Eq. (2) creates a weighting based on the range of temperatures observed in the cell. This procedure approaches the fraction of precipitation that falls as snow.

Logically, Precip_snow ${ }_{x, i}$ cannot be considered to be the total amount of precipitation that falls as snow because the procedure is not reliable on a monthly scale. The obtained values were therefore rescaled linearly (Eq. 3) using an index from 0 (no precipitation as snow estimated for the region) to 1 (maximum precipitation as snow estimated for the region). The index is denoted Potential_accum, and it represents the potential for each individual cell to receive precipitation in a solid state. The rescaling procedure was performed according the following formula:

$$
\begin{aligned}
& \text { Potential_accum }{ }_{x, i}= \\
& \text { [Precip_snow } \left.{ }_{x, i}-\text { Min }\left(\text { Precip_snow }_{i}\right)\right] / \\
& {\left[\operatorname{Max}\left(\text { Precip_snow }_{i}\right) \text { - Min (Precip_snow }{ }_{i}\right) \text { ] }}
\end{aligned}
$$

where Potential_accum ${ }_{x, i}$ is the dimensionless potential precipitation as snow for cell $x$ in month $i$, Min(Precip_snowi) is the absolute minimum value of Precip_snow recorded within the territory in month $i$, and $\operatorname{Max}\left(\right.$ Precip_snow $_{i}$ ) is the absolute maximum value of Precip_snow recorded within the territory in month $i$. Accordingly, Potential_accum is the first non-dimensional index that provides an estimate of the spatial distribution of precipitation fallen as snow for a given month $i$.
(2) The creation of a second index that scales the territory according to the long-term average temperature over the region was also based on climate layers. Because temperature is the most important variable in explaining melting rates (Singh \& Singh 2001, Hock 2003, Shamir et al. 2006), we used the distribution of the mean temperature as a basis for estimating the potential magnitude of melting over the territory. The layer of mean temperature was also rescaled (Eq. 4) from 0 to 1 according to the highest and lowest values of mean temperature recorded in the region:

$$
\text { Potential_melt }_{x, i}=\frac{\operatorname{Tmean}_{x, i}-\operatorname{Min}\left(\operatorname{Tmean}_{i}\right)}{\operatorname{Max}\left(\operatorname{Tmean}_{i}\right)-\operatorname{Min}\left(\operatorname{Tmean}_{i}\right)}
$$

where Potential_melt $t_{x, i}$ is the dimensionless potential magnitude of melting (from 0 to 1 ) of cell $x$ in month $i, \operatorname{Tmean}_{\mathrm{x}, i}$ is the long-term average temperature $\left[\left(T \max _{x, i}-T \min _{x, i}\right) / 2\right]$ for cell $x$ and month $i$, $\operatorname{Min}\left(\operatorname{Tmean}_{i}\right)$ is the absolute minimum value of Tmean recorded within the territory in month $i$, and Max $\left(T \operatorname{mean}_{i}\right)$ is the absolute maximum value of Tmean recorded within the territory in month $i$.

(3) Potential_melt ${ }_{x, i}$ was subtracted from Potential_ $\operatorname{accum}_{x, i}$ to obtain an index that approximates the real snowpack accumulation for a cell $x$ in a given month $i$ :

$$
\begin{aligned}
& \text { Potential_snowpack } \\
& \text { Potential_accum }_{x, i}-\text { Potential_melt }_{x, i}
\end{aligned}
$$

where Potential_snowpack $\mathrm{x}_{, i}$ is the potential magnitude of snowpack in cell $x$ for month $i$. The resulting layer represents the spatial differences in the potential development of snowpack for a given month. Thus, values of potentiality are used to sort the cells within the study area. Values close to 1 represent areas that are expected to record the deepest snowpack (coldest and most humid sectors), while values close to 0 indicate areas in which the probability of snow cover is almost nil because of mild temperatures and/or low precipitation.

In principle, those areas in which snow is most likely to accumulate will remain similar from month to month, albeit modified slightly by the effects of seasonal changes in the spatial distribution of precipitation. The layers of Potential_snowpack $\mathrm{k}_{\mathrm{x}, i}$ were created without considering the conditions of the preceding months, even though the magnitude of snowpack for a given month depends to some degree on the distribution of snow depth during the preceding months. It is difficult to resolve this problem when data are available on a monthly basis. Here, we summed the layers of Potential_snowpack for the second month of the snow season (Potential_snowpack $_{X, D e c}$ because a significant snowpack usually appears from November) and the layer of potentiality for the previous month (Potential_snowpack $\mathrm{X}_{X_{1} \text { Nov }}$ ). For the succeeding month, we applied the following criteria to consider the combined potential snowpack: 
Potential_snowpack_combined ${ }_{x, i}=$

Potential_snowpack $\mathrm{s}_{X, i}+$ Potential_snowpack $_{X, i-1}$

Subsequently, the obtained layer was rescaled from 0 to 1 using the same procedure as that used in Eqs. (3) \& (4):

Potential_snowpack_real ${ }_{x, i}=$

[Potential_snowpack_combined ${ }_{x, i}-$

Min(Potential_snowpack_combined $\left.{ }_{i}\right)$ ] /

$\left[\operatorname{Max}\left(\right.\right.$ Potential_snowpack_combined $\left._{i}\right)$ -

Min(Potential_snowpack_combined ${ }_{i}$ )]

where Potential_snowpack_real ${ }_{x, i}$ is the definitive value of the potential magnitude of snowpack accumulation in cell $x$ for a given month $i$, Min(Potential_snowpack_com$\operatorname{bined}_{i}$ ) is the absolute minimum value of Potential_snowpack_combined recorded within the territory in month $i$, and Max(Potential_snowpack_combined ${ }_{i}$ ) is the absolute maximum value of Potential_snowpack_combined recorded within the territory in month $i$.

Despite the fact that this step involves a degree of subjectivity, the newly obtained layers of potential magnitude of snowpack accumulation include a memory of the snow conditions of the previous months from the beginning of the snow season. The results obtained in the verification process confirm the suitability of this last criterion.

\subsection{Verification and calibration procedure}

Records of snow depth in the study region for January, March, and the end of April were used to: (1) assess the suitability of the obtained maps in reproducing the observed spatial variability in snowpack depth, and (2) assign a representative value of snow depth to values of Potential_snowpack_real, which are obtained as dimensionless units (see Section 3.3).

Despite the fact that we directly used the available snow-depth data (49 observations), we employed modelled average snow-depth values for 400 points for validation and calibration purposes. Modelled average snow-depth values (from 1986 to 2003) for January, March, and April were obtained from the combined influence of altitude, solar radiation, distance to the Atlantic Ocean, and distance to the main divide. The relationship between available snow-depth observations and the terrain characteristics of the Pyrenees was established using Generalized Additive Models (GAMs). In GAMs (Guisan \& Zimmermann 2000), the vector of parametric regression coefficients $b$ is changed by a vector of non-parametric smoothers or functions $s_{p}$. A GAM can be stated as

$$
g(E(Y))=\alpha+f_{1}\left(X_{1}\right)+f_{2}\left(X_{2}\right)+\ldots+\varepsilon
$$

where $g(E(Y))$ is the model response, each predictor variable $X_{n}$ is fitted using a smoothing function $f_{n}\left(X_{n}\right)$, $\alpha$ is the origin and $\varepsilon$ the unexplained variance. Consequently, a GAM involves the addition of different functions fitted to the independent variables in order to predict $Y$ values. Data are fitted with respect to the partial residuals, which are the residuals remaining after removing the effects of all predictor variables. A detailed description of how GAMs are fitted to the data in relation to the employed algorithms can be found in Hastie \& Tibshirani (1987). These models are highly flexible, and their ability to include non-linear relationships between dependents and predictors provides realistic and robust representations of the snow-depth distribution over the Pyrenees (López-Moreno \& Nogués-Bravo 2005).

To obtain more robust relationships between snowpack and topography, models were developed based on the 106 observations available for the Pyrenees. The relatively high density of observations in the Aragonaise territory (49 snow stakes) guarantees a good adjustment of the predicted values to the study area. The models explain 79, 82, and $81 \%$ of the observed snow-depth variability for January, March, and the end of April, respectively. Details of these models and their reliability can be found in López-Moreno \& Nogués-Bravo $(2005,2006)$. The use of modelled snowdepth values was preferred over direct observations because this approach increased the number of cases available for verification and calibration purposes. This procedure was particularly useful in distinguishing the boundary between snow-covered and snow-free areas and in assessing snow accumulation in areas above the highest available observations. This is important because snow poles are only located between 1400 and $2700 \mathrm{~m}$ a.s.l., and large areas at higher elevations remain unrepresented.

\subsection{Modelling potential incoming solar radiation for inclusion in models}

Finally, because the potential magnitude of the snowpack is based on precipitation and temperature data, it does not take into account the effect of local factors that significantly affect the snowpack distribution. The main factors that lead to local variations in snow depth are exposure to incoming solar radiation (Elder et al. 1998, López-Moreno \& Nogués-Bravo 2005, Pohl et al. 2006) and wind redistribution (Winstral \& Marks 2002, Molotch et al. 2005). The effect of wind redistribution is typically neglected because information on wind direction is rare, and simulating its effect at a regional scale is a complex challenge.

Accurate models of incoming solar radiation can be obtained using DTMs and GIS (e.g. McKenney et al. 1999). In the present study, we obtained the potential incoming solar radiation received by each cell between 
December and April. The radiation was expressed in $\mathrm{MJ} \mathrm{m}^{-2} \mathrm{~d}^{-1}$ for clear-sky conditions. The algorithm used to estimate radiation considers the effects of terrain complexity (shadowing and reflection) and the daily solar position (for details see Pons 1996). The algorithm is implemented in the GIS software MiraMon, available at www.creaf.uab.es/miramon.

Once the relationship between the values of potential snowpack derived from climatic layers and the observed snowpack in the Pyrenees is assessed (verification procedure), reliable snow-depth values can be statistically predicted for the entire study area (calibration procedure). This was accomplished using stepwise linear regression models in which the modelled snow depths derived from observational data were the dependent variable, and the layers of Potential_ snowpack_real $l_{x, i}$ and incoming solar radiation the independent (predictor) variables.

\section{RESULTS}

\subsection{Spatial modelling of precipitation and temperature}

Fig. 2 shows examples of monthly temperature and precipitation maps for Aragón obtained from regressionbased interpolation and residual correction. The maps demonstrate significant spatial variability in climatic variables over the region. Different predictors were included for modelling the variables for each month, resulting in clear visual differences when comparing different maps. This is particularly clear for the map of the winter minimum temperature (i.e. minimum temperature during January), when variables that capture the effect of thermal inversion are introduced, or when the models (i.e. precipitation during February) introduce averaged values within a given radius (low-pass filtering) as predictors, regardless of the observed value for the cell.

Table 1 provides details of the quality of the maps in terms of mean bias error (MBE), mean absolute error (MAE), and Willmott's D index, which are measures of the average error of the interpolation (Willmott \& Matsuura 2005). Error estimators were calculated by comparing the modelled values with observations of the $20 \%$ of the dataset reserved for validation. Deviations of predicted temperature never exceed an MAE of $1.1^{\circ} \mathrm{C}$, and the maximum precipitation error for April was $7.17 \mathrm{~mm}$. As is apparent in Table 1, errors were very low with regard to the average of the interpolated variables. Willmott's D values were always close to 1, which indicates a good agreement between predicted and observed values; this confirms the reliability of the obtained maps.

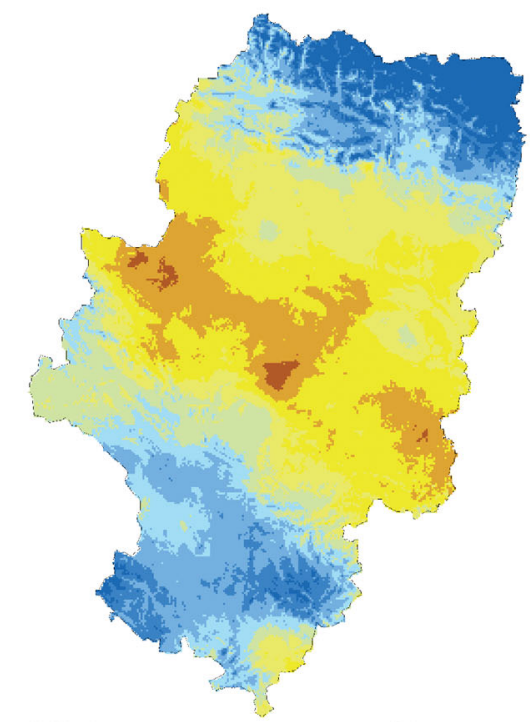

Minimum temperature (January):

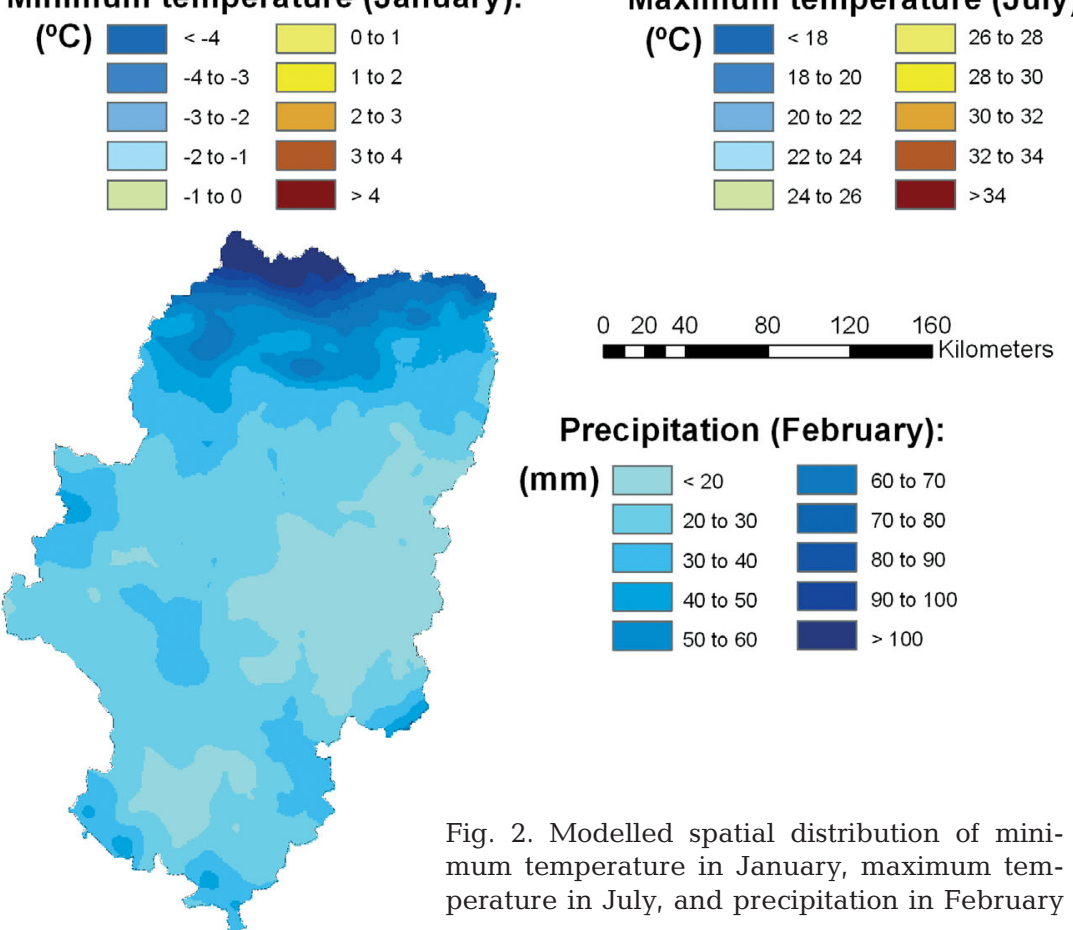


Table 1. Validation of climatic maps. Error estimators calculated using $20 \%$ of independent weather stations. MBE: mean bias error; MAE: mean average error; D: Willmott's D index

\begin{tabular}{|c|c|c|c|c|}
\hline & MBE & MAE & $\mathrm{D}$ & Average \\
\hline \multicolumn{5}{|c|}{ Precipitation (mm) } \\
\hline November & -2.20 & 6.87 & 0.97 & 56.05 \\
\hline December & -0.06 & 6.96 & 0.97 & 54.63 \\
\hline January & -0.34 & 7.26 & 0.96 & 45.30 \\
\hline February & -0.17 & 5.52 & 0.96 & 36.28 \\
\hline March & -0.31 & 5.61 & 0.95 & 36.42 \\
\hline April & -0.01 & 7.17 & 0.96 & 57.34 \\
\hline May & 0.09 & 6.98 & 0.97 & 68.59 \\
\hline \multicolumn{5}{|c|}{ Maximum temperature $\left({ }^{\circ} \mathrm{C}\right)$} \\
\hline November & -0.10 & 0.75 & 0.94 & 13.47 \\
\hline December & -0.08 & 0.82 & 0.90 & 10.00 \\
\hline January & -0.06 & 0.77 & 0.93 & 9.39 \\
\hline February & -0.04 & 0.75 & 0.96 & 11.64 \\
\hline March & 0.03 & 0.98 & 0.95 & 14.70 \\
\hline April & -0.06 & 0.88 & 0.96 & 16.55 \\
\hline May & 0.12 & 1.03 & 0.95 & 20.85 \\
\hline \multicolumn{5}{|c|}{ Minimum temperature $\left({ }^{\circ} \mathrm{C}\right)$} \\
\hline November & -0.13 & 1.05 & 0.89 & 3.80 \\
\hline December & -0.12 & 1.04 & 0.89 & 1.43 \\
\hline January & -0.03 & 1.09 & 0.87 & 0.37 \\
\hline February & -0.22 & 1.04 & 0.89 & 1.27 \\
\hline March & -0.09 & 1.12 & 0.90 & 2.86 \\
\hline April & -0.11 & 0.92 & 0.93 & 4.79 \\
\hline May & -0.11 & 0.90 & 0.94 & 8.45 \\
\hline
\end{tabular}

\subsection{Potential magnitude of snowpack over the territory}

Fig. 3 shows maps of the potential magnitude of snowpack (Potential_snowpack_real) over the region for mid-January, mid-March, and the end of April. Areas for which the selected criteria indicate that snow is probable are assigned values between 0 and 1. Maximum values are recorded in the coldest and wettest areas, whereas probabilities are close to 0 for areas with high temperatures and low precipitation; such conditions are characteristic of large areas of the central Ebro Valley.

The Pyrenees record the maximum potential for snowpack development for the 3 months of interest. The Iberian Range also shows probabilities higher than 0 for snow development; however, the values are much lower than those recorded for the Pyrenees. The extent of areas with high values is greatest in January. Large areas across the Pyrenees record high probabilities of snowpack development, including valley floors and most of the meridional ranges. The Iberian Range also shows large areas with potentialities higher than 0 , but these values rarely exceed 0.2 .

In March, the extent of areas with potentialities greater than 0 is significantly reduced compared with that for January. High values are recorded for all of the

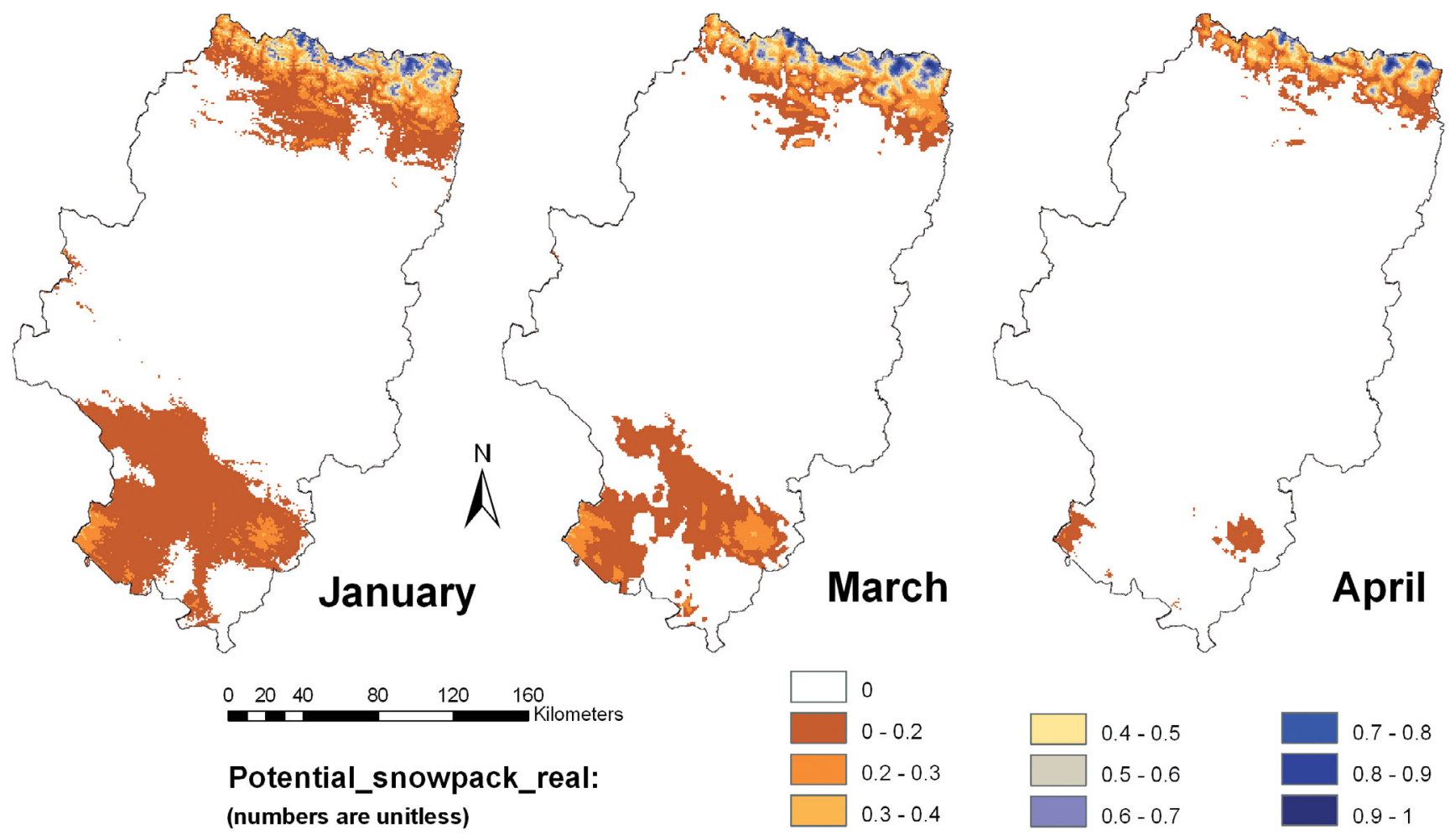

Fig. 3. Distribution of potential magnitude of the snowpack for January, March, and the end of April; values are unitless and scale from 0 (no snowpack) to 1 (maximum snowpack) 


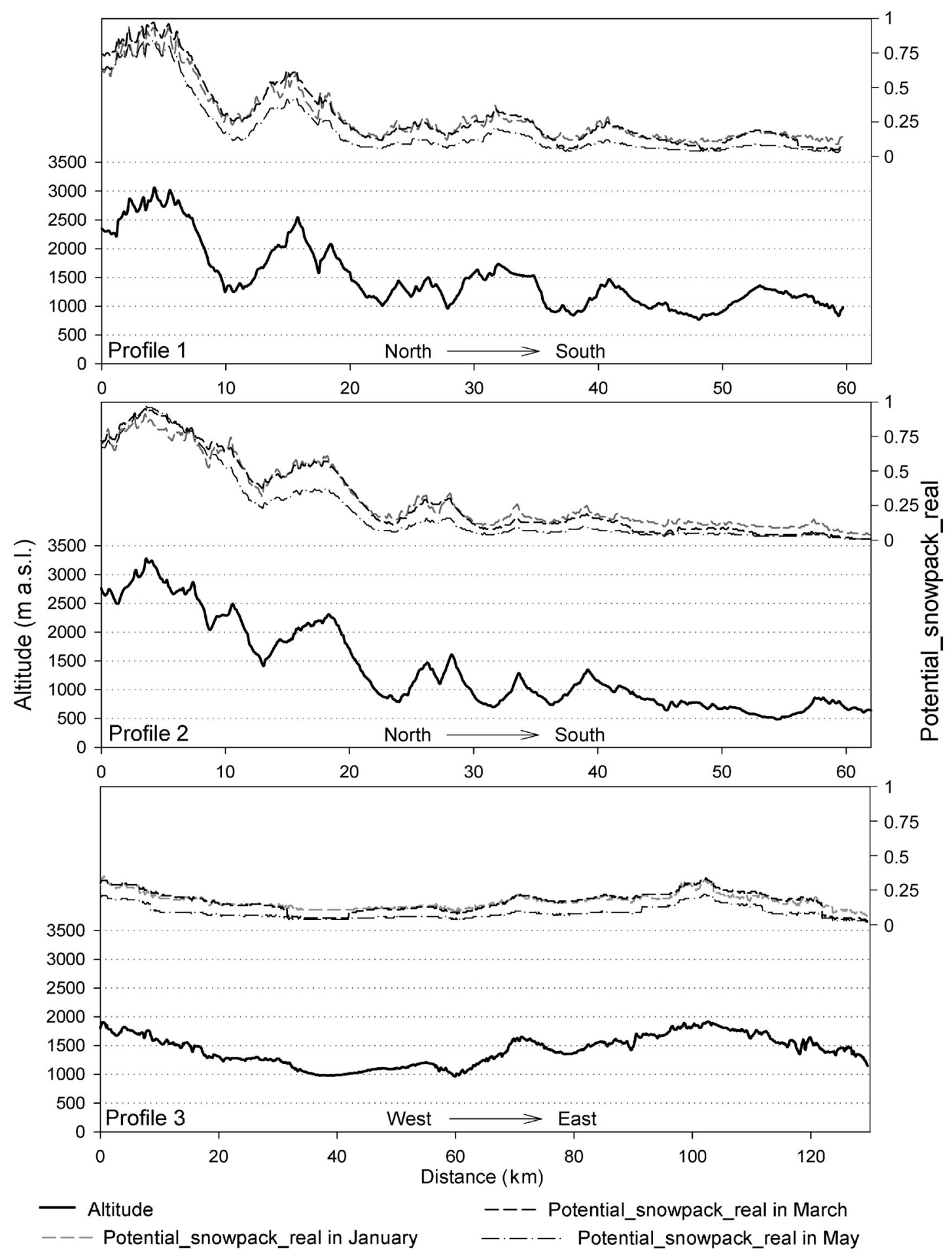

Fig. 4. Spatial variation in potential magnitude of the snowpack and altitude along 3 selected profiles; snowpack values are unitless and scale from 0 (no snowpack) to 1 (maximum snowpack). See Fig. 1 for profile locations

high-altitude parts of the northernmost Pyrenees. In the south of the region, areas with probabilities greater than 0 decrease in extent and tend to become concentrated around the summit areas of the Albarracín, Gúdar, and Javalambre sectors. Finally, at the end of
April, values greater than 0 are only found in high-altitude areas of the Pyrenees and summit areas (with values very close to 0 ) in the Iberian Range. In the Pyrenees, the highest values tend to be concentrated in the east, where the altitudes are higher, and precipitation 
tends to be more important during spring (LópezMoreno \& García-Ruiz 2004).

Fig. 4 provides more detailed information showing how potential magnitudes of snowpack are modelled. The figure shows the spatial variability in potential snowpack magnitude with changing altitude along 3 profiles (see Fig. 1). In all 3 cases, altitude is the dominant control on the observed variability in snowpack magnitudes, but it is also possible to recognize both north-south and west-east gradients in the models. In the Pyrenees (Profiles 1 and 2), the relationship between altitude and snowpack potentiality tends to weaken from north to south. Thus, in Profile 1 (western Pyrenees), the northernmost sectors that are close to $3000 \mathrm{~m}$ a.s.l. (approximately $8 \mathrm{~km}$ from the origin) record potentialities that vary between 0.6 and 0.8 depending on the month, whereas areas at the same altitude located $15 \mathrm{~km}$ to the south record potentialities that vary between 0.4 and 0.6 . This decrease in predicted magnitude reflects the rain-shadow effect of the northernmost ranges at times of northerly and northwesterly flows. The same southward decrease is recorded in Profile 2.

Profiles 1 and 2 show differences in terms of the relationship between altitude and the potential magnitude of snowpack. For example, in Profile 2 at an elevation of $3000 \mathrm{~m}$ a.s.l., values never exceed 0.8 , but they do exceed this value in Profile 1 (to the west). In some cases, the western and eastern profiles also differ in terms of the month that records the highest potential magnitude of snowpack. For example, in the highest sectors of the western profile, the maximum values occur in January and March, while in the eastern profile they occur at the end of April. This discrepancy is a consequence of changes in the seasonal distribution of precipitation in the 2 areas: maximum precipitation in the westernmost areas (close to the Atlantic Ocean) is recorded in winter, whereas in the easternmost areas (closer to the Mediterranean Sea) winter tends to be dry and precipitation increases during spring.

In comparing the Pyrenean profiles (Profiles 1 and 2) with Profile 3 (Iberian Range), it is apparent that the generally low potential magnitudes recorded in Profile 3 not only reflect lower altitudes but also lower precipitation. Thus, values in Profile 3 do not exceed 0.4, even for altitudes of $2000 \mathrm{~m}$ a.s.l. In contrast, within the Pyrenees, potentialities greater than 0.5 are commonly recorded at $2000 \mathrm{~m}$ a.s.l.

\subsection{Verification of the layers of potential magnitude of snowpack and calibration with snow-depth data}

Fig. 5 shows the results of the validation procedure, i.e. the relationships between a sample (400 values) of the potential magnitude of snowpack (Potential_ snowpack_real) and the average snow depth in the Pyrenees modelled from observational data and GAMs (see details in López-Moreno \& Nogués-Bravo 2005, 2006). Because snow depths were modelled using GAMs, some negative values are generated in the figure; these negative values represent snow-free areas. The figures show a good agreement between snow depth and potentialities (coefficients of determination between 0.59 and 0.61 ). This result suggests that the maps obtained from the combination of cli-
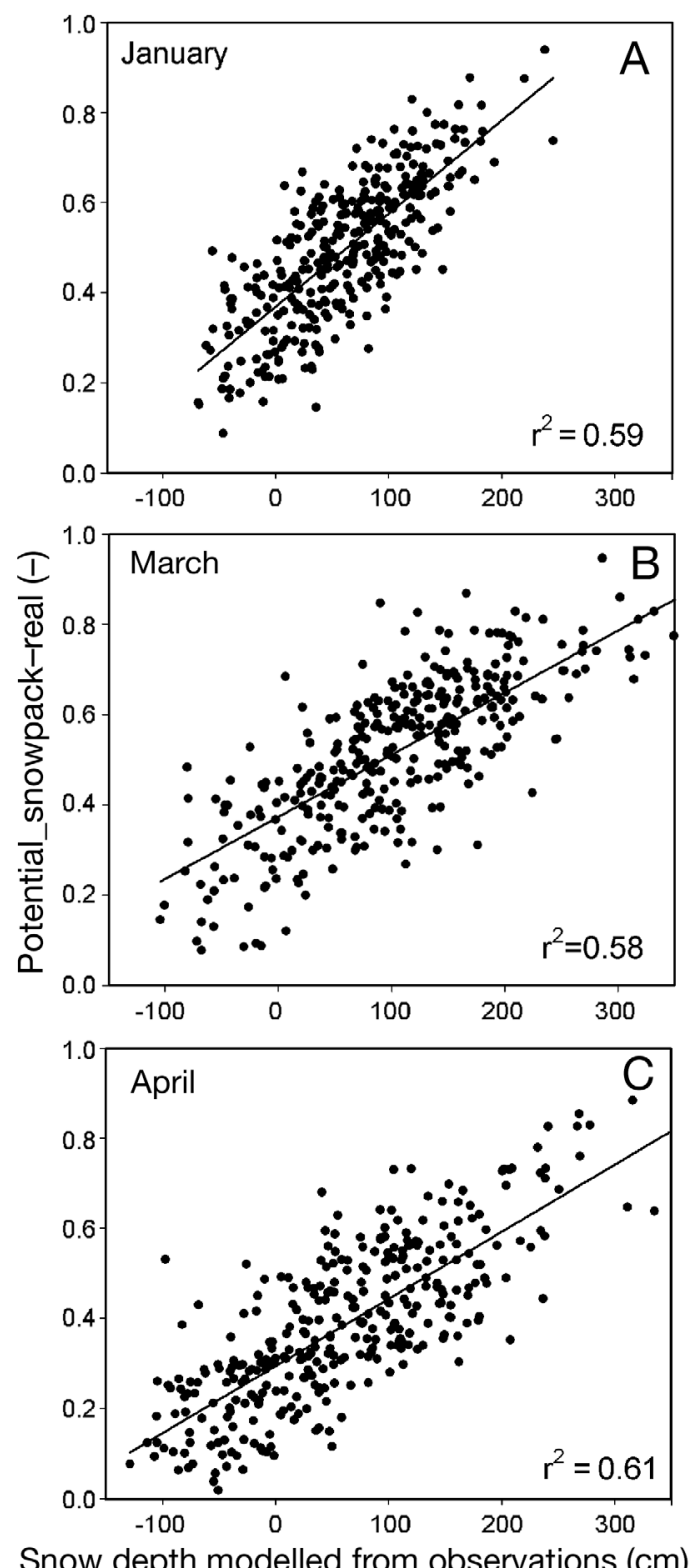

Snow depth modelled from observations $(\mathrm{cm})$

Fig. 5. Results of the validation procedure, showing correlations between potentialities modelled from climate data (values are unitless and scaled from 0 [no snowpack] to 1 [maximum snowpack]) and snowpack modelled from observational data for (A) January, (B) March, and (C) April 
matic layers are able to reproduce the variability in snow distribution over the study region. The figures indicate that snow depth usually shows positive values (occurrence of snowpack) when potential magnitudes exceed 0.2 .

The good agreement observed between potential magnitudes and the observed snow distribution in the Pyrenees enables us to predict the average depth of snowpack over the entire region. In addition, the potential incoming radiation modelled for each cell from the DEM is added as a predictor variable in order

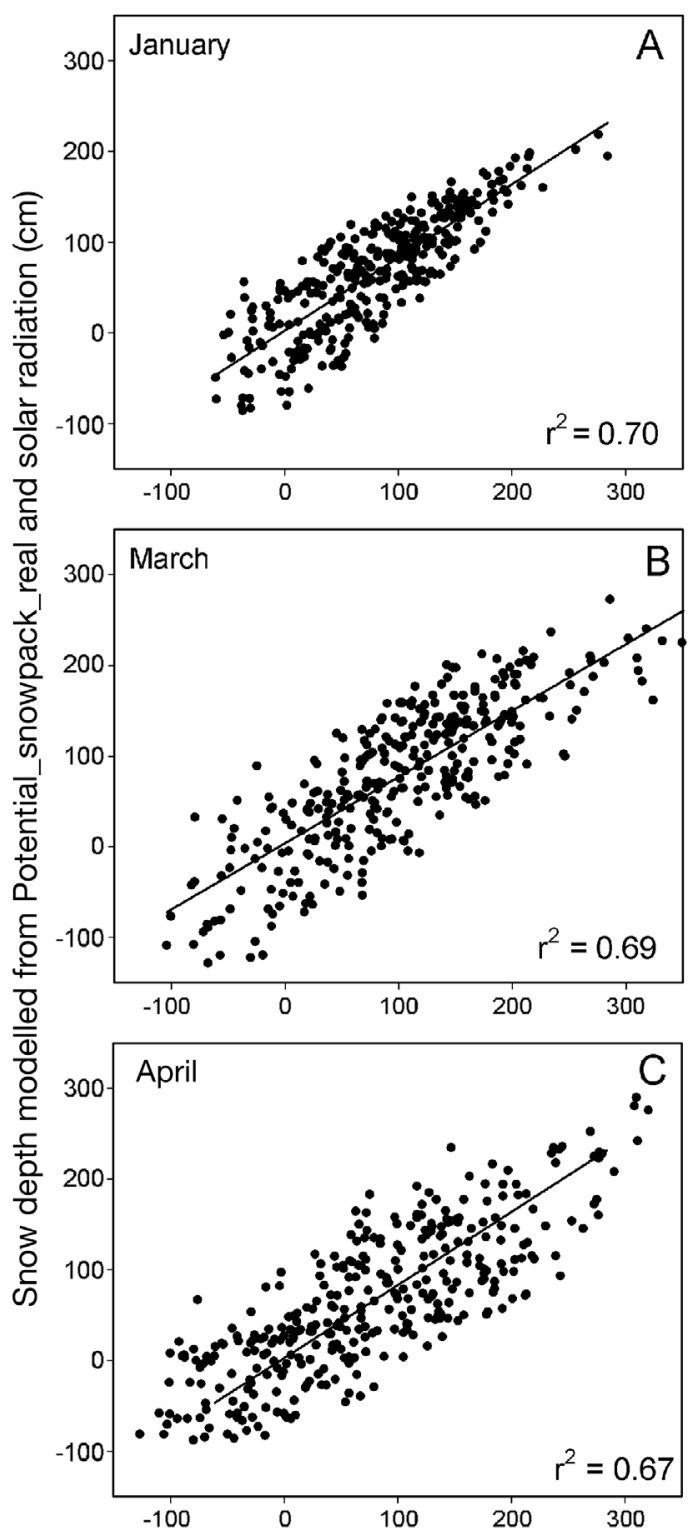

Snow depth modelled from observations (cm)

Fig. 6. Results of the calibration procedure, showing correlations between snowpack modelled from observational data, snowpack modelled from potential magnitudes (obtained from climatic layers), and the spatial distribution of incoming radiation in (A) January, (B) March, and (C) April to capture the spatial variability in snowmelt associated with the complex topography (see details in Section 3.5). Fig. 6 shows the relationship between snow depths modelled from observational data and snow depths predicted when using Potential_snowpack_real and incoming radiation as predictors in a stepwise regression model. In the 3 cases (January, March, and April), both predictor variables were included in the model $(\alpha<0.05)$. The incorporation of solar radiation within the model increases the explained variance to by approximately $10 \%$ compared with snow depth modelled solely using Potential_snowpack_real (Fig. 5).

Maps of the average snow depth predicted from potential magnitudes and solar radiation are shown in Fig. 7. Snow-covered areas are noticeably reduced in extent compared with previous maps of Potential_ snowpack_real. The inclusion of incoming radiation enables us to take into account local conditions related to slope and aspect, leading to a prediction of deeper snow on north-facing slopes, as occurs in nature.

From January until the end of April, warmer temperatures lead to a progressive reduction in the total snow-covered area and snow depth across most of the study area; however, in those areas where high altitude favours snowfall and low melt rates, snowpack continues to increase in thickness. Thus, a deeper snowpack $(>350 \mathrm{~cm})$ is observed at high altitudes at the end of April, especially in the eastern mountains as suggested by the potential magnitude data. In comparison, depths in excess of $200 \mathrm{~cm}$ are rarely observed in January. Outside of the Pyrenees, favourable conditions for snow accumulation in Aragón occur only in limited areas. During January, continuous snowcovered surfaces are only found in the main massifs of the Iberian Range. For these massifs, results indicate that the average snowpack does not exceed $1 \mathrm{~m}$ in depth. Later still, snowpack can only be found in the highest and shadowed slopes of the Albarracín and Gúdar-Javalambre Mountains (see Fig. 1).

\section{DISCUSSION AND CONCLUSIONS}

In this study, we described a method for determining the mean distribution of snow depth over a large territory of $47452 \mathrm{~km}^{2}$. The methodology is based on a simple procedure that requires few data and will undoubtedly provide a useful tool in the many areas for which little information exists concerning snow accumulation.

Establishing robust estimates of snowpack evolution in absolute units (i.e. $\mathrm{mm}$ of snow water equivalent) from temperature and precipitation generally requires at least daily data and sufficient information to estab- 

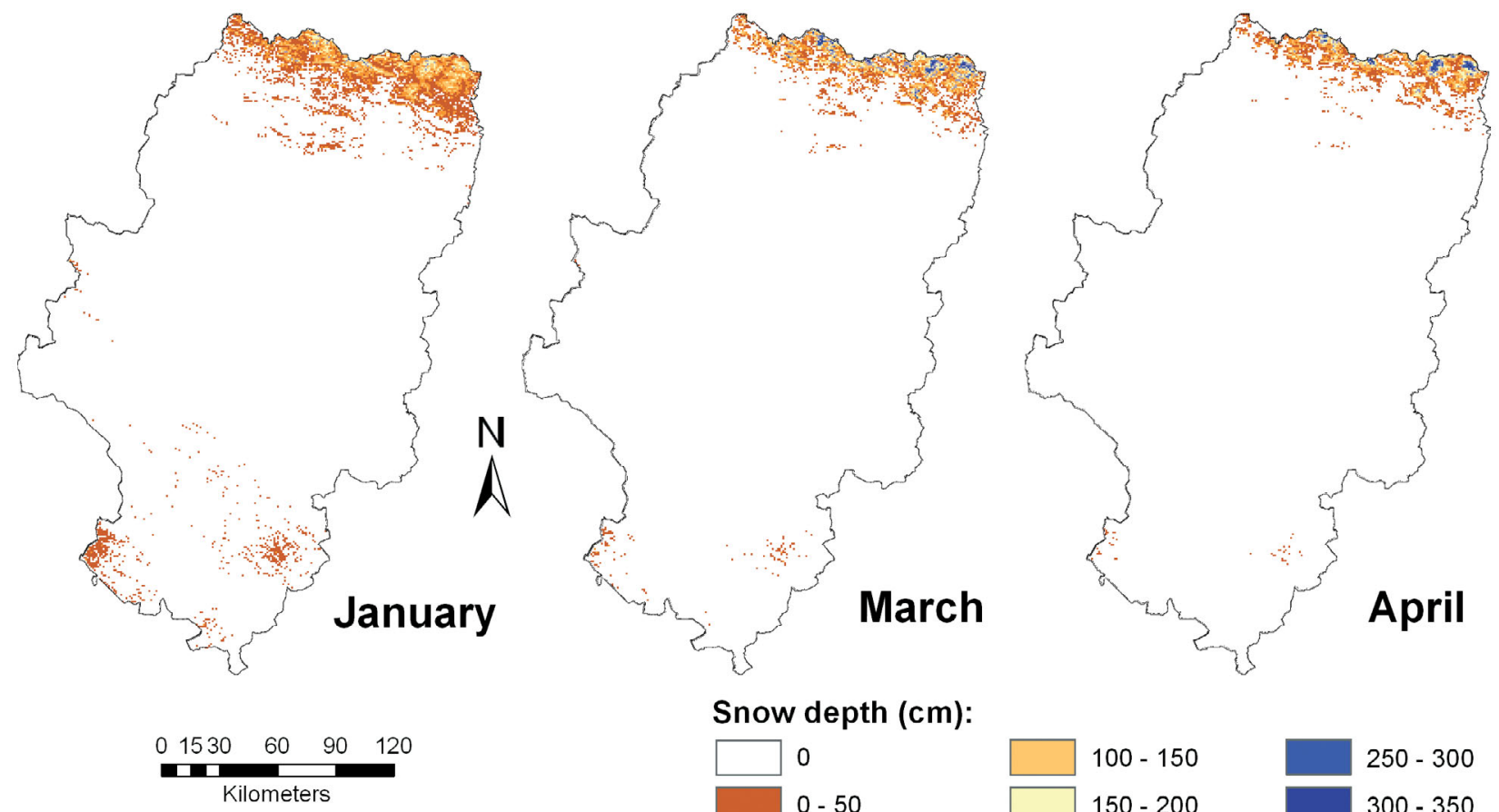

Snow depth (cm):
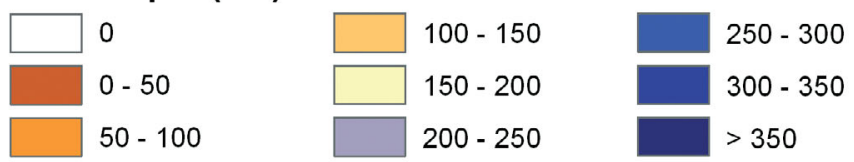

Fig. 7. Distribution of snow depth modelled from potential magnitudes of snowpack and potential incoming solar radiation for January, March, and April

lish solid relationships between temperature and melt rates (degree-day factor, DDF). However, using the present model we require only monthly data, which are usually available even for mountainous regions. The long-term averages of climatic data at a monthly time scale are far easier to manage and map than daily data. In fact, the high degree of spatial variability that typically occurs at short time scales makes it a complex challenge to obtain reliable spatial layers at daily timescales (Jeffrey et al. 2001). New climatic dataacquisition techniques such as weather radar information (Smith et al. 1996) and dense networks of automatic weather stations (Fassnacht et al. 2003) provide new opportunities in this field of research; however, these methods are yet to be operational in most mountain ranges and several technical problems remain to be solved, especially when considering areas of complex terrain.

The compilation of accurate long-term monthly averages of precipitation and temperature layers is required to reliably determine spatial variability in the potential snowpack magnitude. The results of this study confirm the usefulness of regression-based interpolation for making snowpack magnitude maps because this method takes into account the effect of geographical and topographical variables when modelling spatial variability in climatic variables, thus improving the final results (Agnew \& Palutikof 2000, Ninyerola et al. 2000, Daly et al. 2002, 2003, Vicente-Serrano et al. 2003). Error estimators indicate low errors compared with the range of modelled variables. A high degree of accuracy was obtained even when modelling the winter minimum temperature: this generally involves large errors as a consequence of temperature inversions (Daly et al. 2002, Chung et al. 2006).

Using an appropriate combination of climatic layers, we were able to classify the study region according to the potential snowpack magnitude. The classification scheme was based on: (1) the amount of precipitation likely to fall as snow under the given conditions; and (2) the thermal regimen that approximates the observed melting rates. Because monthly data are unable to provide a reliable quantification of the amount of precipitation that falls as snow, and of melting rates, both variables were used to classify the territory according to the potential magnitude of snow accumulation and melt.

Although the results are obtained in dimensionless units (scaled between 0 and 1), the maps of potentiality may be useful for many purposes related to territory management. For example, variations in the potentiality can be used to explain differences in hydrological regimens or to decide upon an appropriate distribution of resources for the management of infrastructure during winter (e.g. snowplough allocation) and the selection of potential areas in which to develop activities 
related to winter tourism. In addition, the predicted amount of precipitation that falls as snow, the melting potential, and the potential magnitude of snowpack can also be obtained for different periods and used as a tool in monitoring climatic variability and longerterm climate change.

The availability of snow-depth measurements for part of the study area enabled the verification of the potentiality maps and the compilation of snow-depth maps in absolute units (cm). The verification procedure demonstrated that variations in the potential magnitude of the snowpack throughout the territory provided an adequate approximation of the main patterns of observed snowdepth distribution. When the effect of local topography on incoming solar radiation was included in the model as a predictor variable, the performance of the snow-depth model improved noticeably. This improvement is explained by the fact that the effect of solar radiation leads to great variability in melt rates within rugged terrain (Elder et al. 1998, López-Moreno \& Nogués-Bravo 2005, Pohl et al. 2006).

The proposed method provides realistic maps of the long-term average snow depth and its evolution throughout winter and spring. Although this study focussed on long-term averages of monthly snow accumulation, the method has potential uses (some requiring minor modifications) for mapping at other time intervals (e.g. weekly, seasonal) and obtaining time series of snowpack (i.e. if Potential_snowpack_real is calculated year by year and not from long-term averages as done here) that can be used to detect those areas that are most exposed to climatic variability and long-term climate change. The latter option would also reveal the distribution of the expected temporal variability in snow accumulation. This is very important in terms of hydrological analysis, the ecology of plants and animals, and planning for economic activities (e.g. agricultural practises and winter tourism).

The simplicity of the method and the fact that it requires few data means that it is appropriate for preliminary studies of snow processes in large areas with limited snow data; however, to optimize the results, it is strongly recommended that a relatively dense network of weather stations is available across any potential study area in order to maximize the accuracy of the climatic layers used as input. In addition, it is desirable that snow information is available across the full range of environments found in the study area.

Acknowledgements. This study made use of methodology described in the report 'The innovation in Aragón' financed by the Department of Environment and Management of the Territory of the Aragonaise Government. The study was also supported by the following projects: PROBASE CGL200611619, CANOA-CGL 2004-04919-C02-01 and CGL2005-
04508/BOS financed by the Spanish Commission of Science and Technology and FEDER, PIP176/2005 financed by the Aragón Government, and 'Programa de grupos de investigación consolidados' (BOA 48 of 20-04-2005). The research activities of J.I.L.M. were supported by postdoctoral fellowships from the Spanish Ministry of Education, Culture and Sports. We thank Drs. José M. García Ruiz and José M. Cuadrat and 3 anonymous referees for their valuable comments.

\section{LITERATURE CITED}

Agnew MD, Palutikof JP (2000) GIS-based construction of base-line climatologies for the Mediterranean using terrain variables. Clim Res 14:115-127

Alexandersson H (1986) A homogeneity test applied to precipitation data. Int J Clim 6:661-675

Basist A, Bell GD, Meentemeyer V (1994) Statistical relationships between topography and precipitation patterns. J Clim 7:1305-1315

Brown RD (1999) Northern hemisphere snow cover variability and change, 1915-1997. J Clim 13:2339-2355

Burrough PA, McDonnell RA (1998) Principles of Geographical Information Systems. Oxford University Press, Oxford

Carroll T, Cline D, Fall G, Li L, Nilsson A (2003) Seasonal snowcover monitoring and modelling for the coterminous United States. Geophys Res Abstr 5:01396

Chung U, Seo HH, Hwang BS, Choi J, Lee JT, Yun JI (2006) Minimum temperature mapping over complex terrain by estimating air accumulation potential. Agric For Meteor $137: 15-24$

Daly C, Neilson RP, Phillips DL (1994) A statisticaltopographical model for mapping climatological precipitation over mountainous terrain. J Clim Appl Meteor 33:140-158

Daly C, Gibson WP, Taylor GH, Johnson GL, Pasteris P (2002) A knowledge-based approach to the statistical mapping of climate. Clim Res 22:99-113

Daly C, Helmer EH, Quinones M (2003) Mapping the climate of Puerto Rico, Vieques and Culebra. Int J Climatol 23: 1359-1381

Elder K, Rosenthal W, Davis R (1998) Estimating the spatial distribution of snow water equivalence in a montane watershed. Hydrol Process 12:1793-1808

Fassnacht SR, Soulis ED (2002) Implications during transitional periods of improvements to the snow processes in the land surface scheme-hydrological model WATCLASS. Atmos-Ocean 40:389-403

Fassnacht SR, Dressler KA, Bales RC (2003) Snow water equivalent interpolation for the Colorado River Basin from snow telemetry (SNOTEL) data. Water Resour Res 39: 1208, doi:10.1029/2002WR001512

García-Ruiz JM, Puigdefábregas J, Creus J (1986) La acumulación de la nieve en el Pirineo Central y su influencia hidrológica. Pirineos 17:27-72

González-Rouco JF, Jiménez JL, Quesada V, Valero F (2001) Quality control and homogeneity of precipitation data in the Southwest of Europe. J Clim 14:964-978

Guisan A, Zimmerman NE (2000) Predictive habitat distribution models in ecology. Ecol Model 135:147-186

Haefner H, Seidel K, Releer S (1997) Applications of snow cover mapping in high mountain regions. Phys Chem Earth 22:275-278

Hastie T, Tibshirani R (1987) Generalised additive model: some applications. J Am Stat Assoc 82:371-386

Hock R (2003) Temperature index melt modelling in mountain areas. J Hydrol 282:104-115 
Jeffrey SJ, Carter JO, Moodie KB, Beswick AR (2001) Using spatial interpolation to construct a comprehensive archive of Australian climate data. Environ Model Softw 16: 309-330

López-Moreno JI (2005) Recent variations of snowpack depth in the Central Spanish Pyrenees. Arct Antarct Alp Res 37: 253-260

López-Moreno JI, García Ruiz JM (2004) Influence of snow accumulation and snowmelt on streamflow in the Central Spanish Pyrenees. Hydrol Sci J 49:787-802

López-Moreno JI, Nogués-Bravo D (2005) A generalized additive model for modelling the spatial distribution of snowpack in the Spanish Pyrenees. Hydrol Process 19: $3167-3176$

López-Moreno JI, Nogués-Bravo D (2006) Interpolating snow depth data: a comparison of methods. Hydrol Process 20: $2217-2232$

Marchand WD, Killingtveit A, Wilén P, Wikstöm P (2003) Comparison of ground-based and airborne snow depth measurements with georadar systems, case study. Nord Hydrol 34:427-448

Martinec J, Rango A, Roberts R (1994) Snowmelt Runoff Model (SRM) user's manual. Department of Geography, University of Bern, Bern

McKenney DW, Mackey BG, Zavitz BL (1999) Calibration and sensitivity analysis of a spatially-distributed solar radiation model. Int J Geogr Inf Sci 13:49-65

Molotch NP, Colee MT, Bales RC, Dozier J (2005) Estimating the spatial distribution of snow water equivalent in an alpine basin using binary regression tree models: the impact of digital elevation data and independent variable selection. Hydrol Process 19:1459-1479

Ninyerola M, Pons X, Roure JM (2000) A methodological approach of climatological modelling of air temperature and precipitation through GIS techniques. Int J Climatol 20:1823-1841

Peterson TC, Easterling DR, Karl TR, Groisman P and 17 others (1998) Homogeneity adjustments of in situ atmospheric climate data: a review. Int $\mathrm{J}$ Climatol 18: 1493-1517

Pohl S, Marsh P, Pietroniro A (2006) Spatial-temporal vari-

Editorial responsibility: Gregory Jones, Ashland, Oregon, USA ability in solar radiation during spring snowmelt. Nord Hydrol 37:1-19

Pons X (1996) Estimación de la radiación solar a partir de modelos digitales de elevaciones. Propuesta metodológica. In: Juaristi J, Moro I (eds) Actas del VII Coloquio de Geografía Cuantitativa, Sistemas de Informaciòn Geográfica y Teledetección. Asociación de Geógrafeos Españoles, Vitoria-Gasteiz, p 87-97. Also available at http://magno. uab.es/atles-climatic/pdf/rad_pot.pdf (in Spanish with English abstract)

Rabus B, Eineder M, Roth A, Bamler R (2003) The shuttle radar topography mission - a new class of digital elevation models acquired by spaceborne radar. ISPR J Photogramm Remote Sens 57:241-262

Shamir E, Konstantine P, Georgakakos P (2006) Distributed snow accumulation and ablation modelling in the American River basin. Adv Water Res 29:558-570

Singh P, Singh VP (2001) Snow and glacier hydrology. Kluwer Academic Publishers, Dordrecht

Smith JA, Jun-Seo D, Baek ML, Hudlow MD (1996) An intercomparison study of NEXRAD precipitation estimates. Water Resour Res 32:2035-2046

Vicente-Serrano SM, Cuadrat-Prats JM (2007) Trends in drought intensity and variability in the middle Ebro valley (NE Spain) during the second half of the twentieth century. Theor Appl Climatol 88:247-258

Vicente-Serrano SM, López-Moreno JI (2006) The influence of atmospheric circulation at different spatial scales on winter drought variability through a semiarid climatic gradient in north east Spain. Int J Climatol 26:1427-1453

Vicente-Serrano SM, Saz-Sánchez MA, Cuadrat JM (2003) Comparative analysis of interpolation methods in the middle Ebro valley (Spain): application to annual precipitation and temperature. Clim Res 24:161-180

Willmott CJ, Matsuura K (2005) Advantages of the mean absolute error (MAE) over the root mean square error (RMSE) in assessing average model performance. Clim Res 30:79-82

Winstral A, Marks D (2002) Simulating wind fields and snow redistribution using terrain-based parameters to model snow accumulation and melt over a semi-arid mountain catchment. Hydrol Process 16:3585-3603

Submitted: June 14, 2006; Accepted: February 7, 2007

Proofs received from author(s): March 28, 2007 